\title{
IAMJ
}

INTERNATIONAL

AYURVEDIC

MEDICAL JOURNAL

\section{MULTIDISCIPLINARY APPROACH IN THE PREVENTION AND MANAGEMENT OF OCULAR HEALTH}

\author{
$\underline{\text { Shraddha S. Bhasarkar }}{ }^{1} \underline{\text { Pradnya R. Bhumbur }}^{2}$
}

${ }^{1}$ PG Scholar, Department of Swasthavritta And Yog, Government Ayurved College, Nagpur, Maharashtra, India ${ }^{2}$ PG Scholar, Department of Shalakyatantra, Government Ayurved College, Nanded, Maharashtra, India

Corresponding Author: bhasarkarshraddha@gmail.com

https://doi.org/10.46607/iamj0909032021

(Published online: March 2021)

Open Access

(C) International Ayurvedic Medical Journal, India 2021

Article Received:02/02/2021 - Peer Reviewed:08/02/2021 - Accepted for Publication:17/02/2021

\section{Check for updates}

\section{ABSTRACT}

In today's era of globalization, prevention plays an important role in the field of health science. Excess usage of gadgets like use of computers, ipads and smart phones is leading to over functioning of eyes. Eyes are the windows to the mind. among the five sense organs Ayurveda gives prime importance to eyes. Now-a-days changed work expectations requiring prolonged working hours in front of computers, nutritional deficiency, pollution, stress, indiscriminate use of topical ocular drugs and increased incidence of allergic disorders, etc. lead to eye diseases. Suffering from ocular disorders with uncorrected refractive error in children result into adverse effect on quality of life and significantly affect their vision, education and psychosocial development. Working in artificial light either dim light or bright light is another culprit for deterioration of ocular health so emphasis should be laid on the prevention of these, as eyes are the most important and sensitive of five sense organs in human body. Ayurveda is one of the greatest gifts to mankind. In Ayurveda, selected classical daily regimes like Netraprakshalana (eye wash), Anjana (collyrium), Snana(bath), Padabhyanga (foot massage with oil), Nasya (nasal application of drugs), wholesome and unwholesome dietetics are promoted as high-end measures for the maintenance of eye-health. Various Netravyayamas (eye exercises), Yogasanas, Pranayamas, Neti and Trataka are said to be beneficial for the same cause. The main aim of this review is to promote and spread the awareness about maintenance of ocular health and prevention from the earlier causation of ocular diseases. 
Keywords: ocular health, daily regime, sense organs

\section{INTRODUCTION}

Ayurveda has the distinction of being the oldest medical system known to man and the oldest and most comprehensive spiritual teachings in the world. Out of the eight specialties of Ayurveda, Shalakya Tantra is one of the eight clinical specialties of Ashtanga Ayur$v e d a$, devoted to diseases related to eyes, nose, ears and throat. In the present era, people are suffering from a wide number of diseases among which the ocular diseases have gained special importance. Among the five sense organs i.e. eyes, ears, nose, tongue and skin Ayurveda give prime importance to the eyes. Ayurveda states 'Sarvendriyanamnayanampradhanam.' The eyes are the windows into one's health as the eyes are the only organ in the body where a doctor can have a clean view of our blood vessels, nerves and connective tissue. In the present era, world community is facing an unprecedented pandemic of novel corona virus disease (COVID 19) caused by severe acute respiratory syndrome corona virus 2(SARS CoV 2). The disease has spread globally and to stop its spread many activities like, work from home, online coaching classes, online schools, webinars, online lectures, etc., were started just as a preventive measure to stop the pandemic. But as like every action has equal and opposite reaction likewise these online activities have got its repercussions on the ocular health. These activities have brought a great stress and strain on our very precious eyes. Nowadays, practice of using of the spectacles is carried out right from the younger kids to the geriatric age group. There may be a number of reasons for this. Excessive use of computers, laptops and mobile phones leads to the over functioning of eyes. Stress and strain lead to the over functioning of eyes. Stress and strain, increased workload and reduced sleeping hours is directly or indirectly affecting the ocular health. This may result in the occurrence of minor to major eye diseases.

Eyes allow us to understand and navigate the world around you. According to Ayurveda, three factors being responsible for the causation of all type of diseases including ophthalmic problems too ${ }^{[1]} 1$.Incompatible contact of eye with visual objects (Asatmendriyarthasamyog) 2.misuse of intellect (Pragyaparadha) 3.abnormal cycles of seasons (Rutuviparyay)

In the present era, ocular diseases have become a major threat to the mankind. If a person is endowed with all other sensory facilities, strength, beautiful appearances, etc. but without eyesight he will be useless as an insect for a blind person though he is rich, day and night are all equal and entire world seems to be useless. Globally, approximately 250 million people suffer from varying degrees of vision $\operatorname{loss}^{[2]}$ hence, significance of multidisciplinary approach becomes mandatory. Ayurveda offers many safe, effective and simple techniques for maintaining ocular health. Also, diet is key lifestyle factor that can have long term effects in ocular health. Various Netravyayamas (eye exercises), Yogasanas, Pranayamas, Neti and Trataka are also said to be beneficial for the same cause. Also, diet is a key lifestyle factor that can have long term effects in ocular health. ${ }^{[3]}$

\section{Materials and Methods:}

An overall study was done on the matter based on the preventive eye care in Ayurveda. A comprehensive search was done on the matter related to the various promotive and preventive eye care in Ayurveda. Descriptions were gathered from different ayurvedic Samhita and the recent research papers were also found out and studied from the digital platforms available viz, PubMed, google researcher, research gate, google scholar, etc. the findings were then analyzed according to the present day perspective and put forth in this paper.

Modalities as per Ayurveda for the prevention of ocular health:

Acharyas have described the daily regimen of preventive healthcare and maintenance of health of body and mind. They specially emphasized on eye healthcare and defined the slaves for betterment of eyes. As per Ayurveda, the best way to treat a disease is to avoid its cause ${ }^{[4]}$. If we avoid the causes which would further 
cause harm to the ocular health, we prevent them from getting deteriorated. We should avoid the following causes for the betterment of our eyes ${ }^{[5]}$

1. Avoidance of exposure to water immediately after getting heated from exposure to sun, heat or fire.

2. Avoiding practices of watching very far objects.

3. Circumventing practices of observing very minute objects.

4. Escaping untimely sleeping habits.

5. Avoidance of indulging in anger, sorrow, fear and exertion

6. Suppression of natural urges like controlling of tears should not be followed.

Dinacharya (daily regimen)

Dinacharya is the term made out of two words, Dina which refers to the day and Charya refers to the regimen which should be done regularly ${ }^{[6]}$. The daily regimen helpful in the prevention of ocular health is mentioned as follows:

1) Bramhamuhurtauthana ${ }^{[7]}$ (waking up early): A healthy person should get up early in the morning on Bramhamuhurta to protect his life after considering the condition of digestion of food. During this time there is abundance of nascent oxygen which easily mixes with hemoglobin forming oxy haemoglobin reaching the tissues and boosts the immune system. The cornea and lens are the avascular structures of the eye which gets nutrition directly by oxygen present in the $\operatorname{air}^{[8]}$

2) Netra prakshalana (eye wash): Netraprakshalana or eye wash with decoction of Lodhra (symplocusracemosus) with Amalaka (emblica officinalis) decoction or with cold water helps in maintaining the constant clear vision ${ }^{[9]}$

3) Ushahjalpan (water intake in early morning) and Nasajalpan (water intake through nose): daily intake of water in early morning either mouth or through nose purify the whole GIT and ensure good vision. Doing Gandusha i.e. keeping mouthful of cold water 2-4 times a day will help to maintain eyesight $^{[10]}$.

4) Anjana (collyrium): There are two types of Anjana, mainly practiced in daily regimen: a) medically processed antimony Sulphide (Sauveeranjana) and b) solid extract of berberisaristata (Rasanjana). The Sauveeranjana type of collyrium is applied to eyelashes every day and Rasanjana is used once at interval of five or eight nights for stimulation and secretion. Among all Mahabhutas, Tejas dominates the eye and is susceptible to Kaphadosha. Hence, the measures alleviating Kapha are beneficial for clear vision. Anjana helps remove the Doshas and Malas in the form of tears and provides cleanliness to eyes as a result. Eyes become clear and beautiful with thick eye lashes and excel the vision ${ }^{[1]}$.Anjana is used in treating various ailments of eye like cataract. Apart from its curative effects in various eye disorders, it can be adopted as a daily regimen to protect eyes and to maintain good vision ${ }^{[12]}$.

Daily habit of Anjana practice found not only useful for good appearance of eyes but also removes burning sensation, itching, dirt (excretion), moistness and pain of eyes, accommodation to high and low light and prevent disease development ${ }^{[13]}$. Action of Anjana can be attributed for dissolving the accumulated vitiated Kapha and draining it out. It dilates the blood vessels, increases the blood flow and maintains the integrity of Netrastrotas. Anjana is used in treating various ailments of eye like cataract. Apart from its curative effects in various eye disorders, it can be adopted as a daily regimen to protect eyes and to maintain good vision.

Contraindication of Anjana includes a person who is on fasting, who has taken bath on head, who is awaken at night and person with fever should not apply collyrium.

5) Snana (bathing): bathing with cold water or water with slightly less temperature than body temperature from the head always promotes eye health and indicated to people until or unless other contraindications. But bathing with warm water on head always makes unhealthy effect on eyes. Cold water head bath enhances the blood circulation, improves digestive activity, removes tiredness, sleepiness and exhaustion of the body.

6) Shiroabhyanga: Shiroabhyanga is the procedure of applying oil to the head and gives nourishment to all sense organs. Daily application of medicated oil 
on head especially Murdha region, is strengthening to eyes and preventive measure for sense organs disorders. It acts as Drishtiprasadan. It nourishes the optic nerve which is responsible for vision. Shiroabhyanga enhances the flow of CSF, thus strengthening the nervous system relaxes the muscles improves the blood circulation and oxygenates the brain.

7) Padaprakshalana (feet wash) ${ }^{[14]}$ : As per ayurvedic texts, two Siras (veins) are situated in the center of the feet (soles) which are significantly connected to eyes. This helps to transmit the effect of medications applied over the soles in the form of oil massage and promote the eye health and helps secure ocular health. These veins vitiated by the accumulation of malas (dirt, assault of soles by hard substance and stone) or over pressure bring about abnormality of eyes. Washing of feet with clean water confers clear vision.

8) Padatradharana: walking without footwear on irregular surface causes harm to eyes so use of footwear is beneficial for eyesight. Hence, every person should perform massage over soles with oil, washing them well and should use foot wears as a simple and promotive approach for eye problems.

9) Padabhyanga: application of oil over soles always bestows sleep comfort and maintains vision. In a clinical study of the effect of Tilataila Padabhyanga on eye strain of 60 patients for 15 days, observed $70 \%$ improvement in weakness of eye and $33.33 \%$ showed improvement in heaviness of eye ${ }^{[15]}$

10) Chatradharana ${ }^{[16]}$ : the use of umbrella protects our eyes from sun, wind, dust, etc. and from harmful ultraviolet radiation. Chatradharana is considered as Chakshushya i.e. beneficial to eyes.

11) Nasya (nasal drops): Nasya Karma is the procedure of instillation of medicinal drops to the nose. It nourishes the organs above the clavicle known as Nasya. Nasal cavity structures have direct communication with the sensorineural structures of brain, and this is natural gateway to brain. One who practices Anutaila as Pratimarshya Nasya (small dose of medicated oil) 1-2 drops in each nostril, gets a better vision and power of other sense organs remain intact and defects free. In a study it was found that AnutailaNasya with Yashtimadhu Ghrita is effective in computer vision syndrome and effect persists even after treatment without any complications. Yashtimadhughrita Tarpana and Anutaila Nasya is effective in blurred vision ${ }^{[17]}$. Also in a study, preventive impact of Pratimarshya Nasya with unique reference to Anutailam led arbitrarily on 40 people or aggregate time of 1 month watched the mean score of Drishtikshamta (eye force) at pattern was $2.45+-0.47$ at end of study ${ }^{[18]}$. Hence, the strength of sense organs is increased by Nasya and is not attacked suddenly by disorders.

\section{Digital Eye Strain ${ }^{[19]}$ :}

Digital eye strain is nowadays a major problem of today's generation. In the present era, it's almost impossible to go without a smartphone, tablet, computer or other digital device at least once during the day. Although tremendously useful, digital devices when used for extended periods of time can be tiring to the eyes. The effect of digital eyestrain is not known to be serious or cause any long-termeffects, but they can certainly cause discomfort to your eyes and vision and thus hamper the ocular health.

\section{Modalities for prevention of digital eye strain:}

The blinking activity should be done more often. The computer monitor's position should be adjusted in such a way that the neck does not undergo any strain. Avoid neck, shoulder and back pain by keeping your computer at an optimal distance and position on your desk. The center of the computer screen should be about 15-20 degrees below eye level and at least 15 inches away from the eyes. Use of computer glasses should be taken into consideration, the computer glasses help your eyes focus when looking at a computer screen they help reduce glare and eye strain Ocular health and Trayopstambha (three sub pillars of life)

There are three pillars of health, technically called as the Trayopstambha are:

1. Ahara(dietary regimen)

2. Nidra (sleep pattern)

3. Bramhacharya (conduct like lord brahma) Ahara, Nidra and bramhacharya are the three pillars of life which hold and maintain the disease-free life. On proper succeeding food should be taken at proper 
time. Suppression of hunger leads to weakness in visual perception. Ahara should be taken in a limited quantity (Matravat Ahara). Matravat Ahara is that which does not disturb the Prakriti of a person and digest in an appropriate period of time. Viruddhaahara (which is not suitable for the body) may lead to reduced vision and blindness. Nidra (sleep) revitalizes the mind and body. Sound sleep is absolutely necessary for the eyes. During sleep, the eyes are at complete rest. Sleep is important because it affects our mental, physical and emotional wellbeing. Acharya Sushrut ${ }^{[20]}$ says that sleep is enjoyment of pleasure by body and sense organs. As it is being a chief nourisher of the body. During sleep, the eyes are at complete rest and recollect functional capacity. Bramhacharya is concerned to self-control of sense organs. Bramhacharya refers to control over physical limits. Persons undergoing sexual intercourse during the menstrual phase lose their visual health ${ }^{[21]}$.

Vegadharana (suppression of natural urges) ${ }^{[22]}$

Suppression of natural urges has bad effect on wholebody, but suppression of tear and sleep especially leads to diseases of eye. Suppression of urges causes Vataprakopa, leading to weakness of ocular tissues and strain to eyes. A faulty lifestyle involving continuous exposure to computers and mobiles due to prolonged working habits and webinars may contribute to hampering the ocular health

\section{Yoga practices for prevention of ocular health:}

Nowadays, in the era of ipads, laptops and smart phones it is of sole importance to maintain the ocular health. Yoga, pranayama and mudra and Shatshuddhi Kriya can be of great help in the prevention of from many eye diseases also these are cost effective methods in the maintenance of ocular health. These procedures provide strength to the eyes and also improve vision to some extent.

\section{Asanas $^{[23]}$ :}

In Yoga Asana palming, swinging and shifting movement of eyes, Yogasanas like Shirshasana (headstand), Matsyasana (fish pose), Sinhasana (lion pose) and Shavasana helps relax all the muscles of body including eyes. After a busy day helps reduce stress and strain of the body, mind and eyes. Palming pro- cess is the technique in which we rub our own palms and then touch them to eyes. When palming process is used after meals it helps in prevention of Timira (refractive error in development of cataract).

\section{Pranayama:}

Pranayama means extension or expansion of the dimensions of 'Prana'. A good balance of mental status is essential for proper functioning of the eyes because sense organs can perceive the objects only in the presence of mind.

In the Bhramari Pranayama, vibrations are created in the body during Pranayama, help nourish the muscles of the eyes, among others proper practices of Nadi Shodhana and Bhramari Pranayama increase stress tolerance, provide calmness, improves circulation and reduce the muscle tension. All these have promotive action in the eye health ${ }^{[24]}$

Mudra $^{[25]}$

Mudra means seal, mark or gesture. Mudra is a spiritual gesture on energetic seal of authenticity employed in iconography and spiritual practice. Different Mudras are useful in the prevention and cure from eye diseases. Vaayu Mudra helps in eradicating the feeling of heaviness in eyes and to prevent loss of eyelashes and also useful in the prevention of eyelid problems. Prithvi Mudra helps for curing cataract problems. $\mathrm{Va}$ yu Mudra helps remove vitiated air from eye and gives relief from burning sensation and dry eyes.

\section{Use of Rasayana for the prevention and mainte-} nance of ocular health:

The appropriate use of Chakshushya and Rasayan Dravyas will help to maintain the health of the eyes and prevent age related problems. The use of Yashtimadhu, Ghrita and Triphala act as Rasayana. When triphala is used along with honey and Ghrita at nights at night on daily basis it strengthens eye sight ${ }^{[26]}$.

\section{Trataka:}

Trataka means to gaze. There are three types of Trataka ${ }^{[27]}$.

1. Antartratak

2. Madhyatratak

3. Bahyatratak

Trataka vitalizes vision by accelerating blood circulation in and around the areas of the eyes and also neu- 
tralizes the eye infections by destroying the microbes through tears. By directing the gaze at the eyebrows centers, the olfactory nerves and the optic nerves are stimulated as a result the central and autonomic system are awakened. There is a close relationship between the mind and vision. Thus, Trataka not only maintains the physical health of the eyes but also helps in controlling the mind. It causes soothing effect on the cranial nerves, thus enabling the mind to become one-pointed and therefore helps in establishing clear vision ${ }^{[28]}$.

Neti:

Neti is the process of cleaning the nasal cavity using either water or a catheter. There are two types of Neti ${ }^{[29]}$ :

\section{1) Jalaneti}

\section{2) Sutra neti}

There are many benefits of Neti. Neti stimulates the sensory organs in head, it stimulates tear ducts, improves vision, improves focus and boosts memory power. Daily practice of Neti, thus helps in the maintenance of ocular health.

\section{Dietary approach for maintenance of ocular health.}

Since diet and nutrition have been linked with most common diseases affecting the elderly, dietary modification and nutritional supplementation for the prevention and treatment of eye diseases has attracted a considerable amount of scientific attention. Diet is a key lifestyle factor that can have long term effects on ocular health. One should include green vegetables in the diet as they are packed with lutein and zeaxanthin antioxidants that lower the risk of developing macular degeneration and cataracts. Lutein and zeaxanthin are carotenoids that are major components of macula pigment. They are proposed to have a protective role in the retinal care through their antioxidant properties and ability to act as a filter for blue light ${ }^{[30]}$. The following products are good nutritional supplements ${ }^{[31]}$.

Eggs: The egg yolk is a prime source of lutein and zeaxanthin plus zinc, which helps reduce your macular degeneration risk.
Citrus and berries: These fruits are powerhouse of vitamin $\mathrm{C}$ which has been shown to reduce the risk of developing macular degeneration and cataract.

Almonds: They are filled with vitamin E, which slows macular degeneration.

Fatty fishes: These are rich in DHA, a fatty acid found in the retina, low levels of which have been linked to dry eye syndrome.

Pathya Ahara: The person who is fond of his healthy eyes should follow a proper diet regime and use dietary products such as Yava (barley), Godhuma (wheat), Lohitshali (red rice), Shastika, Mudga (green gram) etc. which are old and which mitigate Kapha and Pitta mixed with more of Ghrita (butter fat), vegetables, meat of animals dwelling in forests, Dadima (pomegranate), Sita (sugar), Saindhava (rock salt), Triphala, Draksha (grapes), rain water(i.e. pure cold water) for drinking ${ }^{[32]}$.

Apathya for ocular diseases:

1. One should not suppress the natural urges especially of Nidra (sleep) and Ashru (tears) this affects the normal functioning of lacrimal gland. 2) one should avoid Adhyashana (food should not be taken until and unless the food taken before is digested properly). 3) one should protect himself from anger.4) one should avoid daytime sleep and night awakening; this disturbs the normal functions of rods and cones causing eye strain. One should avoid heavy and spicy food and medicine which would cause constipation to maintain proper eye health ${ }^{[33]}$.

\section{DISCUSSION}

Human eyes play a vital role in day to day lives and are perhaps the most precious gifts we have. But according to the present working scenario our eyes suffer the most of stress and strain. The excessive use of these delicate organs cause deterioration in the ocular health and as a result, the person suffers from refractive errors, cataract and other ocular diseases. Emphasis on the comprehensive eye care and attention needs to be given to eliminate avoidable blindness from the country. The eye promotive regimen delays the degenerative process in the retina and focal point and nourishes the visual structure. Eye exercise and ayur- 
vedic measures are found to be supportive in the eye care. A person can attain excellent potentiality of the body and sense organs by the usage of daily regimen in their life. The therapies like Yogasana, Pranayama, Mudra, Trataka and Neti reduce the tension in eye muscles as well as reduce general tension. They also tone the eye muscles up and keep them elastic. Thus, they improve functioning of the eyes and helps to overcome various eye related problems and also useful in the prevention of other diseases and delaying the aging process.

\section{CONCLUSION}

As we all know that our disturbed lifestyles and improper dietary habits have led in increase of the diseased visual state. If we put a proper light in the correction of lifestyles it may help us in prevention of turning diseased state of eyes. If few subtle changes are brought in our lifestyle and dietary habits it can help in achieving an optimum visual health. Ayurveda helps in the maintenance of our visual health through its different modalities like Padabhyanga, Nasya, Anjana, Snana, Ashchotana, etc. along with this if we bring changes in our dietary habits like taking timely meals, taking fruits like Dadima, Draksha, etc. this would help us in the prevention of eye diseases and also help in recovering from the disease if the disease has already occurred. Preventive practices should be promoted by everyone as they prove to be the most useful and effective measures for maintenance of visual health and prevention from ocular diseases. The subtle changes brought in the diet helps in the proper management of visual health by providing proper nutrition to the ocular structures.

In this paper, an attempt has been made to bring forth all the modalities which can be used as a preventive measure and also as a part of Chikitsa in the treatment of Netrarogas and therefore helps delay in the degeneration of the structures this helps in the maintenance of visual health. The Trataka Kriya helps in the proper maintenance ofproper eye care. The Yogasanas mentioned here helps in the strengthening of ocular structures and thus prevents ocular disorders.
Thus, by following proper Dinacharya (daily regime), Trataka Kriya, Yogasana, Pranayama and proper balanced diet one can achieve and maintain a very good ocular health. Along with a healthy diet and regular exercise helps in protecting vision from stresses of light, tension and environmental toxins.

\section{REFERENCES}

1. Tripathi B, Charaka Samhita, Sutrasthan, Chaukhamba Sanskrit Pratisthan, Edition 2009, Chapter 1,Dirghajivitiyadhyaya, Verse 54, pg no 26

2. Flaxman et al, global causes of blindness and distance vision impairment 1990-2020: a systematic review and meta-analysis -lancet glob-health 2017,5,e1221-e1234

3. lawrenson j. g., nutrition and eye health, mdpi,2019

4. Kale S, Charak Samhita, Chaukhamba Sanskrit Pratishthan, Edition 2013, VimanSthan, Vyadhitrupiyavimanadhyaya, Verse 15, Page No. 607.

5. Athawale P.G., Drushtarth Sushrut Chintan, Uttartantra, Godavari publishers and book promoters, edition 2008, chapter 1, Aupdravik Adhyay, verse 26,27-page no. 350

6. Samgandi K, textbook of Swasthavrittamritam, first edition: 2019, page no. 17

7. Tripathi B., Ashtang Hriday, Chaukhamba Sanskrit Pratishthan, Sutrasthan, Chapter 2, Dincharyaadhyaya, Verse1, Page No.26

8. Sihota R, Parson's diseases of the eye, Elsevier publications, $20^{\text {th }}$ edition, chapter 2 , page no. 21

9. Mukhopadhyaya $\mathrm{b}$, et al, promotive and preventive eye care in ayurved, international journal of health sciences and research ISSN 2049-957

10. Mishra b, Bhava prakashvidyotini hindi commentary first part, chaukhamba Sanskrit bharti, edition 2007, verse 318

11. Kale S., Charak Samhita, sutrasthan, chaukhambasansnkritpratishthan, chapter 5, matrashitiya, verse no. 15 , page no. 96

12. Tresa maria job et al, significant analysis of dinacharya with special reference to preventive ophthalmology, world journal of pharmaceutical and life sciences, SJIF, impact factor 5.088

13. Ambikadutta Shastri, sushrutsamhita, chaukhamba Sanskrit sansthan, edition 2015, Uttartantra, chapter 18, kriyakalpadhya, verse 52 .

14. Prof Murthy KR Srikanth, Sushruta Samhita text English translation vol. 2. Chaukhamba orientalis Varanasi: Reprint ed-2010.24 verse 69-75, page no.231 
15. Joshi n, clinical study of the effect of TilaTaila Padabhyanga on eye strain. Int. J. Res. Ayurved Pharma DOI: 10.7897/2277-4343.07250, Vol 2, issue 2 MarApr 2016

16. Prof Murthy KR Srikanth, Sushruta Samhita Text English Translation Vol. 2. Chaukhamba Orientalis Varanasi: Reprint Ed-2010.24 Verse 75, Page No.231

17. Gaikwad N, Study the efficacy of yashtimadhughritatarpana and anutailanasya in the treatment of computer vision syndrome, ISSN 23205091

18. Patil Y. et al- Study of preventive effect of pratimarshyanasya with special reference to anu tailam (an ayurvedic preparation), IJRP, ISSN 2230-8407, Vol 3, Issue 5, 2012

19. https://visualhealth.com/what-is-digital-eyestrain/

20. Ambikadutta Shastri, Sushrut Samhita, Chaukhamba Sanskrit Sansthan, Edition 2015, Chikitsa Sthan, Chapter 24, Anagatbadhapratishedh Adhyay, Verse 88, Pg No. 138

21. Mishra b, Bhavaprakash, Chaukhamba Sanskrit Bhavan, edition 2018, $1^{\text {st }}$ part, Chapter 5, dincharyadiprakarnam, verse 303, pg no.152

22. Shastri K, Charak Samhita Vidyotini Hindi Commentary, Sutrasthana, Choukhamba Sanskrit Pratisthan, Edition reprint 2009 Chapter 7, verse 22-page no. 156.

23. Satyanand Saraswati, Yoga Publications Trust, munger, Bihar, India, edition 2013, Intermediate group, inverted asanas pg no. 251

24. Patrikar V. G, Sampurna Swasthavrittavidnyan, dhanvantari publishers, Chapter 24, Pranayama, pg no. 251.

25. www.astrogle.com/yoga/mudras.to cure-eye-problemshtml cited on $24^{\text {th }}$ oct, 2015

26. Tripathi B, Ashtang Hriday, Chaukhamba Sanskrit Pratishthan, edition 2015, Chapter 8, Matrashitiya, verse 44, page no. 143

27. Patrikar V.G., Sampurna Swasthavrittavidnyan, dhanvantari publishers, chapter 23, Pranayama, page no. 362

28. www.yogavimoksha.com/2014/trataka/concentrationgazing/cited on $11^{\text {th }}$ feb 2016

29. Patrikar V.G., Sampurna Swasthavritta, Dhanvantari Publishers, Chapter 24, Yogic Shuddhikriya, Page No. 267

30. Arunkumar et al, what do we know about the macular pigment in AMD: the past, present and the future, eye 2018,32992-1004, PubMed

31. https://visualhealth.com/beyond-carrots
32. Tripathi B, Ashtang Hriday Chaukhamba Sanskrit Pratishthan, Uttarsthan, Chapter 16, Sarvaakshirog, Verse 62, Pg No. 998

33. Tripathi B, Ashtang Hriday, Chaukhamba Sanskrit Pratishthan, edition 2015, uttartantra, chapter 16, sarvaakshirogpratishedhyay, verse 64, 65, pg no. 998.

\section{Source of Support: Nil \\ Conflict of Interest: None Declared}

How to cite this URL: Shraddha S. Bhasarkar \& Pradnya R. Bhumbur: Multidisciplinary Approach In The Prevention And Management Of Ocular Health. International Ayurvedic Medical Journal \{online\} 2021 \{cited March, 2021\} Available from: http://www.iamj.in/posts/images/upload/572_579.pdf 